\title{
Teaching Video NeuroImages: Almost No Eye Movements to the Left
}

Michael Strupp, MD, Claudia Frenzel, and Jun Thorsteinsdottir, MD

Neurology ${ }^{\circledR}$ 2021;96:e2353-e2354. doi:10.1212/WNL.0000000000011234

Figure MRI of the Pons

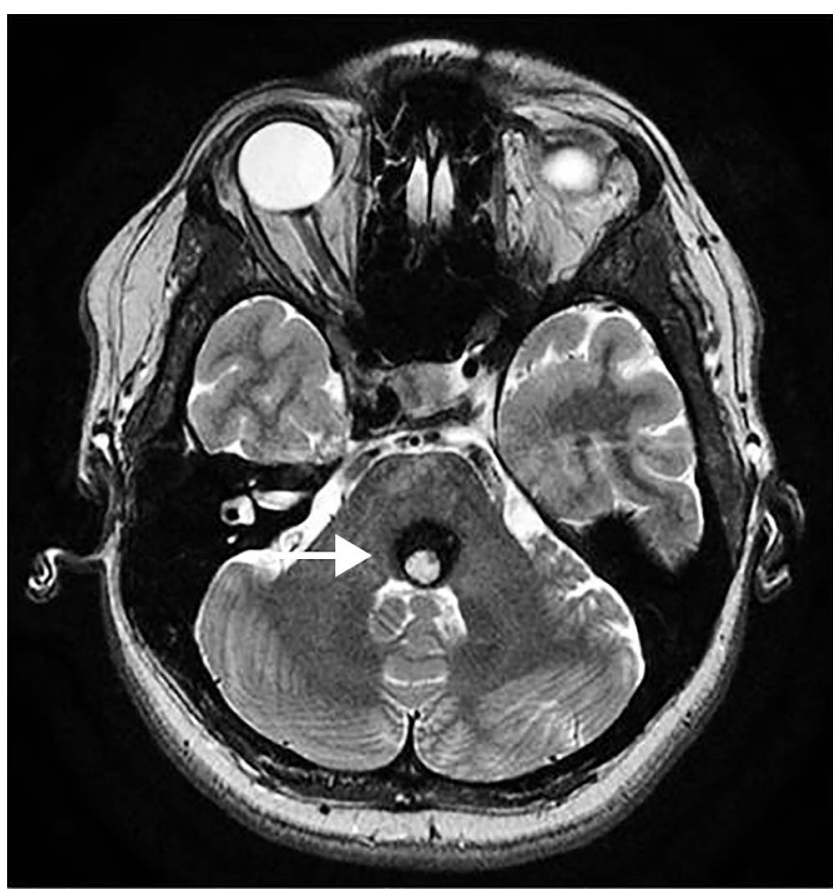

T2-weighted MRI in axial view; white arrow shows pontine cavernoma at the level of the abducens nuclei.

A 31-year-old patient had acute dizziness and lateropulsion to the right. Neuro-ophthalmologic examination revealed (1) a saccade and gaze palsy to the left (video 1, part A), (2) a "halfpathologic" head-impulse test to the right (video 1 , part B), but (3) bilaterally normal adduction during convergence reaction (video 1 , part $\mathrm{C}$ ), findings typical for a left abducens nuclear palsy. It was caused by a histologically proven cavernoma in the tegmentum pontis (figure). To differentiate an abducens nuclear palsy from a combined lateral and contralateral medial rectus muscle palsy, one must test the convergence reaction, which goes via direct pathways to the oculomotor nucleus. ${ }^{1}$

\section{Study Funding}

No targeted funding reported.

\section{Disclosure}

M. Strupp is Joint Chief Editor of the Journal of Neurology, Editor in Chief of Frontiers of Neuro-otology, and Section Editor of F1000; has received speaker's honoraria from Abbott, Actelion, Auris Medical, Biogen, Eisai, Grünenthal, GSK, Henning Pharma, Interacoustics,

\section{Correspondence}

Dr. Strupp

Michael.Strupp@

med.uni-muenchen.de
MORE ONLINE

- Video

$\rightarrow$ Teaching slides:

links.lww.com/WNL/

B282

From the Department of Neurology and German Center for Vertigo and Balance Disorders (M.S., C.F.) and Department of Neurosurgery (I.T.), Ludwig Maximilians University, Munich, Campus Grosshadern, Munich, Germany.

Go to Neurology.org/N for full disclosures. Funding information and disclosures deemed relevant by the authors, if any, are provided at the end of the article. 
Merck, MSD, Otometrics, Pierre-Fabre, TEVA, and UCB; is a shareholder of IntraBio; acts as a consultant for Abbott, Actelion, Auris Medical, Heel, IntraBio, and Sensorion; and is the distributor of M-glasses. Go to Neurology.org/ $\mathrm{N}$ for full disclosures.

\section{Appendix Authors}

\begin{tabular}{|c|c|c|}
\hline Name & Location & Contribution \\
\hline $\begin{array}{l}\text { Michael Strupp, } \\
\text { MD }\end{array}$ & $\begin{array}{l}\text { Department of } \\
\text { Neurology and German } \\
\text { Center for Vertigo and } \\
\text { Balance Disorders } \\
\text { (DSGZ), Ludwig- } \\
\text { Maximilians University, } \\
\text { Munich, Campus } \\
\text { Grosshadern, Germany }\end{array}$ & $\begin{array}{l}\text { Observation, } \\
\text { conception, recruitment } \\
\text { and examination of the } \\
\text { patient, interpretation } \\
\text { of the data, drafting the } \\
\text { manuscript }\end{array}$ \\
\hline
\end{tabular}

Appendix (continued)

\begin{tabular}{lll}
\hline Name & Location & Contribution \\
\hline Claudia Frenzel & $\begin{array}{l}\text { Department of } \\
\text { Neurology Ludwig- } \\
\text { Maximilians University, } \\
\text { Munich, Campus } \\
\text { Grosshadern, Germany }\end{array}$ & $\begin{array}{l}\text { Neuro-opthalmologic } \\
\text { examination of the } \\
\text { patient, interpretation } \\
\text { of the data, drafting the } \\
\text { manuscript }\end{array}$ \\
$\begin{array}{l}\text { Jun } \\
\text { MDorsteinsdottir, }\end{array}$ & $\begin{array}{l}\text { Department of } \\
\text { Neurosurgery, Ludwig- } \\
\text { Maximilians University, } \\
\text { Munich, Campus } \\
\text { Grosshadern, Germany }\end{array}$ & $\begin{array}{l}\text { Observation, } \\
\text { conception, recruitment } \\
\text { and examination of the } \\
\text { patient, interpretation } \\
\text { of the data, surgery of } \\
\text { the patient, drafting the } \\
\text { manuscript }\end{array}$ \\
& &
\end{tabular}

\section{Reference}

1. Leigh RJ, Zee D. The Neurology of Eye Movements, 5th ed. Oxford: Oxford University Press; 2015. 


\section{Neurology}

\section{Teaching Video NeuroImages: Almost No Eye Movements to the Left Michael Strupp, Claudia Frenzel and Jun Thorsteinsdottir}

Neurology 2021;96;e2353-e2354 Published Online before print November 18, 2020

DOI 10.1212/WNL.0000000000011234

This information is current as of November 18, 2020

\section{Updated Information \&} Services

\section{Subspecialty Collections}

Permissions \& Licensing

Reprints including high resolution figures, can be found at: http://n.neurology.org/content/96/18/e2353.full

This article, along with others on similar topics, appears in the following collection(s):

All Neuro-ophthalmology

http://n.neurology.org/cgi/collection/all_neuroophthalmology

Clinical neurology examination

http://n.neurology.org/cgi/collection/clinical_neurology_examination Ocular motility

http://n.neurology.org/cgi/collection/ocular_motility

Other cerebrovascular disease/ Stroke

http://n.neurology.org/cgi/collection/other_cerebrovascular_disease_s troke

Information about reproducing this article in parts (figures,tables) or in its entirety can be found online at:

http://www.neurology.org/about/about_the_journal\#permissions

Information about ordering reprints can be found online:

http://n.neurology.org/subscribers/advertise

Neurology ${ }^{\circledR}$ is the official journal of the American Academy of Neurology. Published continuously since 1951, it is now a weekly with 48 issues per year. Copyright () 2020 American Academy of Neurology. All rights reserved. Print ISSN: 0028-3878. Online ISSN: 1526-632X.

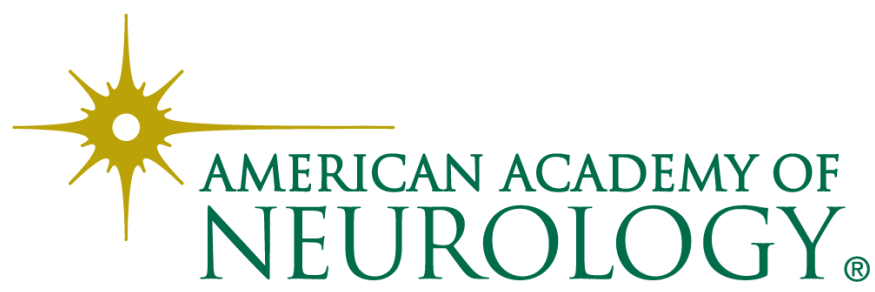

